\title{
SOCIO-POLITICAL ACTIVITY OF THE BROTHERS MYKHAILO AND BOHDAN HORYN IN MODERN UKRAINIAN HISTORIOGRAPHY
}

\author{
Bohdan Verbytskyi \\ Postgraduate Student, National Pedagogical Dragomanov University, Ukraine \\ e-mail: bo4epur@gmail.com, orcid.org/0000-0003-1578-5210
}

\section{Summary}

In recent years there has been a growing academic interest in studying the socio-political activities of particular personalities of the dissident human rights movement in the Ukrainian SSR, which led to declaration of Ukraine's independence in 1991.

The article has analyzed the researches and historical literature of Ukrainian scientists who have mentioned the activity of Mykhailo and Bohdan Horyn in their scientific contributions.

Based on the factual materials, the author has divided into groups and characterized historical works dealing with different aspects of dissident, samizdat (literal meaning "self-publishing"), socio-political and state-building activities of the Horyn brothers.

Following the results of processed data, it has been established that the role of M. and B. Horyn, as one of the key personalities who facilitated the achievement of Ukraine's independence, was poorly elucidated in the scientific literature. Thus, the study of activities of the above figures contributes to a better understanding of the historical processes taking place in the USSR in the second half of the $\mathrm{XX}^{\text {th }}$ century.

Keywords: historiography, dissidents, political prisoners, samizdat, Ukrainian dissident movement, human rights movement.

DOI: https://doi.org/10.23856/4222

\section{Introduction}

In the context of modern Ukrainian state building, both social and scientific interest in the historical processes associated with the evolution of Ukraine's independence is steadily on the rise.

The current state of the socio-political situation in Ukraine brings about the issue of the role of prominent figures, who uncompromisingly struggled for the realization of the idea of creating an independent state and the elimination of the Soviet system as to be harmful and detrimental to the Ukrainian people.

The brothers Mykhailo Mykolaiovych and Bohdan Mykolaiovych Horyn are notable among such outstanding historical personalities who worked hard to restore the Ukrainian national consciousness of the population and strengthen Ukraine as a sovereign state.

The socio-political activity of the Horyn brothers has become the focus of attention of the academic community over the recent decades. It has been caused by the considerable interest associated with the personalities who made a significant contribution to Ukraine's independence. It is worth remarking that in the 1990s - early 2000s the general public knew the names of Viacheslav Chornovol, Levko Lukianenko, Stepan Khmara who were iconic figures of the dissident and human rights movements and before long - the leaders of democratic opposition parties, active participants of the socio-political life of the young sovereign state. Instead, the activity of the brothers M. and B. Horyn, whose contribution to the revival of Ukrainian statehood was no less remarkable, was undeservedly dumped out in the cold by researchers. 
It is worthwhile to state that when M. Horyn completed intense political and public activities in 2006 and B. Horyn had given up active state and political action in 1998, there were no critical and objective studies which came to grips with the main periods of their becoming socio-political figures, conditions in which values, worldview and objectives towards the development of the Ukrainian society as a part of the USSR were shaped. Taking into account the before mentioned, it stands to reason that the personalities of the Horyn brothers need in-depth study under the framework of a special research.

Considering the available academic literature, covering general problems of the functioning of the Ukrainian national liberation movement in the second half of the $\mathrm{XX}^{\text {th }}$ century and individual aspects of activities of the Horyn brothers, it seems expedient to divide the historiographical research into the following groups:

- general works which deal with the specifics and patterns of the Ukrainian dissident and human rights movements and the engagement of the Horyn brothers in them;

- special academic papers which focus on activities of the Horyn brothers in the socio-political life of Ukraine.

\section{The former historiographical group of sources}

The contributions of the former historiographical group examine the activity of the Horyn brothers in the context of dissident and human rights movements in Ukraine. The first publications on the history of the Ukrainian dissident movement appeared in the early 1990s. Among them, the scientific manuscripts of the following researchers should merit attention: O. Bazhan, V. Baran, Yu. Zaitsev, B. Zakharov, H. Kasianov, Yu. Kurnosov, A. Rusnachenko.

In particular, historian Yu. Kurnosov has paid heed to the issue of origin and evolution of the opposition movement in the UkrSSR in his monograph "Dissidence in Ukraine: ("60s the early " 80 s of the $\mathrm{XX}^{\text {th }}$ century)" (Kurnosov, 1994). However, the paper cursorily regards the activities of the Horyn brothers.

Researcher H. Kasianov carries out a thorough analysis of the dissident movement as a socio-cultural phenomenon and examines the issues of formation and activities of the opposition in the Soviet state in details (Kasianov, 1995). The paper demonstrates the division of the dissident movement by directions and trends in accordance with the tactical and strategic tasks of the participants, focuses on the national, territorial and social composition of the dissident movement, and highlights the methods of applying repressions against dissidents. In the author's opinion, the movement of defiance emerged and existed exclusively due to the intellectuals, including the Horyn brothers. Historian H. Kasianov concurrently notes that there were some controversies between Kyiv and Galician centers of dissidents concerning the methods of struggle of the Sixtiers. The author marks the Horyn brothers insisted on using the experience of the Organization of Ukrainian Nationalists (OUN) in promoting the views and ideas of the union. At the same time, another activist of the dissident movement I. Svitlychnyi considered it expedient to develop the "culture-mongering" direction as a safe and the only possible option in the existing conditions.

The study of the features of the formation and development, periodization of the national liberation movement during the "Khrushchev Thaw" occupies pride of place in the work of A. Rusnachenko (Rusnachenko, 1998). The author thoroughly distinguishes the directions of the opposition movement - national, human rights, cultural, and labor. The monograph's special part is devoted to reviewing the activities of the local dissident centers, their role in the establishment of the all-Ukrainian opposition network of dissidents. A. Rusnachenko 
points out the Horyn brothers had a clear and distinct role in the opposition movement, which involved important function of distributing samizdat on the way towards the independence, albeit over time.

Therefore, historians O. Bazhan (Bazhan, 2000) and Yu. Danyliuk (Danyliuk, 2000) focused in their collective papers on the beginning period of crystallization and consolidation of the Ukrainian national movement. It is worth mentioning the authors carried out the analysis of dissemination of opposition sentiments against the Soviet system among the religious movements and groups, including national minorities and ethnic communities, and identified their specifics. The researchers summarized that following independence, many leading figures of the UHG (Ukrainian Helsinki Group) took a firm state position, which is confirmed by the active participation of the Horyn brothers in the parliamentary election campaigns of the 1990s and the election of B. Horyn as the deputy of the first and second convocations, and M. Horynof the first convocation of the Verkhovna Rada of Ukraine.

Researcher B. Zakharov attempted to carry out a general examination of the human rights movement in Ukraine (Zakharov, 2003). Having characterized a full range of dissident movements and trends in the UkrSSR, the author drew particular attention to the Ukrainian national movement, including individual aspects of the activity of the Horyn brothers. In his opinion, the personalities under consideration deliberately chose the way of uphill and dangerous battle against oppressions of rights and freedoms by the Soviet totalitarian system. The author states that brothers' father belonged to the OUN underground and often was subjected to arrest. In that situation, the Horyn brothers were brought up in such an atmosphere that any day could be last for the whole family. Special attention was fixed on the activities of Lviv Club of Creative Youth "Prolisok" (snowdrop) in the operation of which the brothers took the most active part. The paper marks a leading role of the Horyn brothers in printing and distributing samizdat which became an effective mechanism in sharing reliable information about the real state of affairs in the Soviet society, ideological bias of the Soviet system and repressions against dissident figures. The central role of M. Horyn in creating the UHG program documents is highlighted. In general, the contribution is informative and based on the numerous interviews of participants of the liberation movement.

The paper "Challenges to the system: Ukrainian Liberation Movement of the latter XXth century" written by the participant of the liberation movement I. Hel, which was published after the author's death in 2013 and compiled by I. Yezerska, is of deep scientific interest (Hel, 2013). The author traces the evolution of the Ukrainian liberation movement of the latter half of the XXth century and draws attention to the activities of particular personalities and associations. The author also stresses the significant role of the Horyn brothers in the dissident movement. It is noted their major part in preparing and distributing samizdat, creation the network for disseminating truthful information. The issue of permanent oppressions of opposition activists in Ukraine is individually studied. Moreover, the paper establishes the patterns of ideological transformations of dissidents that were reflected in the shift from cultural positions to the formulation of well-managed policy inputs and program documents designed to invigorate the battle for the national idea. It is emphasized the Horyn brothers together with Ivan Svitlychnyi were pioneers in adjusting the mechanism of distribution of the nationalistic documents among the Ukrainian people.

Reference books devoted to the dissident movement in Ukraine and its particular personalities are especially noteworthy. One of the most consistent of them is the encyclopedic reference book "Resistance Movement in Ukraine: 1960-1990" (Resistance Movement in Ukraine, 2010). It covers the events taking place on the territory of Ukraine from the 1960s 
to the proclamation of its sovereignty. The reference book consists of the biographic data of relevant personalities, information on the creative heritage and press bibliography of the movement's participants. The encyclopedia also includes the biographical backgrounds of the Horyn brothers and their creative achievements. Many articles are dedicated to representatives of the diaspora and foreigners who shared samizdat across the West.

"International Biographic Dictionary of Dissidents of Central and East European countries and the Former Soviet States" completed due to the efforts of Kharkiv Human Rights Protection Group is similar in content and a writing style (International Biographic Dictionary of Dissidents, 2006). It contains the substantial biographies of dissidents, involving M. and B. Horyn, and throws light on the milestones of their activities until the book's publication. A great contribution of the authors is manifested in a complex dictionary which enumerates the available opposition organizations in the period under study and the literature they spread.

The papers which deal with the issues of activity of the Ukrainian Helsinki Group and its role in the opposition movement deserve special mention. The most noticeable among them is the first volume of the paper having the same title compiled by V. Ovsienko (The Ukrainian Helsinki Group of Promoting the Implementation of the Helsinki Accords, 2001). It is dedicated to the HGG personalities, including the Horyn brothers.

O. Boiko's monograph "Ukraine in 1985 - 1991: the main trends of socio-political development" is devoted to the evolution of the Ukrainian national democratic movement during the years of "perestroika" (literal meaning "restructuring") (Boiko, 2002). The author considers the national democratic movement in the context of sweeping political changes in Ukraine. The Soviet public-political organizations, including UHU (Ukrainian Helsinki Union) and NRU (the People's Movement of Ukraine), which were also established due to the efforts of the Horyn brothers are highlighted.

O. Miahka's publication is a well-argued manuscript which touches upon the issue of specifics of interaction between the leading activists of the Ukrainian national liberation movement (Miahka, 2008). The scientist has focused on the analysis of the views of the opposition to the regime concerning the matter of the state status of Ukraine. It is marked that in this regard, there were disputes and controversy between UHU (L. Lukianenko, M. Horyn, V. Chornovil) and the representatives of conservative intellectuals - I. Drach, D. Pavlychko and I. Dziuba. The dissident wing regarded its strategic goal only as Ukraine's independence, while the "literature triumvirate" stranded for the possibility of gaining real sovereignty of Ukraine, but within the USSR. It is determined the thesis of creating a sovereign Ukrainian republic under the new union treaty, which provided for an option of establishing direct relations with other Soviet republics, was a compromise idea for the groups. It is beyond argument that such an approach was quite insecure and temporary, as the opposition leaders adhered to their convictions, formally declaring a position that had no real prospects.

The researches devoted to the development of Ukrainian samizdat are worth noticing as well. Thus, O. Obertas's monograph specified activities of the Horyn brothers and their likeminded fellows in producing and distributing clandestine press (Obertas, 2010). The scientific manuscript of $\mathrm{O}$. Naumova traces the process of publication of essays of the Ukrainian samizdat by the West publishers (Naumova, 2014).

\section{The latter historiographical group of sources}

The scientific studies of the latter group are directly dedicated to the public-political and culture-mongering activities of the Horyn brothers. It is worth mentioning the endeavors 
of Ukrainian scientists to create autobiographic portraits of M. and B. Horyn. T. Batenko's contributions were pioneering in this field: they illustrated particular life periods, the formation of worldview milestones and values of the fighters for the independence of Ukraine (Batenko, 1995; Batenko, 1997). Moreover, there was a shot at outlining the periods of opposition activities of the personalities under study. For the scientific investigations, the author used unique interviews with $\mathrm{M}$. and B. Horyn not available at that moment, documents from their personal files, correspondence with team-mates and like-minded fellows.

Another attempt to evaluate the activity of B. Horyn reasonably was expressed in Yu. Zaitsev's publication devoted to the $70^{\text {th }}$ anniversary of the prominent public figure (Zaitsev, 2007). In this research, which contains several topical sections, the author seeks to make some conclusions of stormy and consistent life struggle of B. Horyn. The estimation of academician Ya. Isaievych, who decisively states that B. Horyn belongs to that cohort of personalities (the same M. Shashkevych belonged to in the XIXth century), who can be called "activators" of the national consciousness and identity, is eloquent.

The author stresses the views of B. Horyn towards the building of an independent state highlighting that he is characterized by the evolutionary approach, enthusiastic support of the Ukrainian national idea and state position proclaiming "the nation can't exist without the state". Despite an advanced level of the article, it doesn't cover the activities of B. Horyn as the People's Deputy, the role in establishing Ukraine as a sovereign and full-fledged state on the political picture. Taking into account the above, there is the evident conclusion about a particular fragmentary nature of the mentioned paper that, in turn, doesn't downplay the importance of the publication as one of a few currently available.

O. Shanovska's scientific article seems to be quite interesting and informative (Shanovska, 2016). The scientist considers character traits and worldview of M. Horyn based on the KGB (the Committee for State Security) archives given the experience of a long term of imprisonment and the fight against the Soviet repression regime. It is emphasized his inviolability and commitment to the idea of struggle for establishing the Ukrainian state, eliminating the totalitarian system, guarantees of rights and freedoms of an individual and the nation.

The article of Ya. Seko, which deals with the features of activities of the Horyn brothers in terms of the creation and functioning of Lviv Club of Creative Youth "Prolisok", is not less important (Seko, 2015). In particular, it is determined that in the late 1950s - early 1960s, an individual group of the creative intellectuals, which consisted of artist S. Karaffa-Korbut, literator M. Ilnytskyi, sculptor T. Bryzh and writer V. Luchuk, was formed around the personality of B. Horyn as well as his brother Mykhailo. It is highlighted that the creative center headed by M. Kosiv was founded in Lviv under the influence of Kyiv allies in late April 1963. The paper marks that B. Horyn didn't take the helm of it due to an advantage of the latter among the party leadership and significant moderation in views. Nevertheless, the Horyn brothers occupied a crucial role in the group operation by maintaining the fundamental awareness-raising activities (literary soirees) which were well-liked and popular with young people.

T. Shelemei dedicated a research to the public activities of M. Horyn in 1961-1965 (T. Shelemei, 2007). The author finds out all the factors which affected the formation of the opposition views of dissidents, covers his practical activities related to the organization of cultural events involving Lviv intellectuals, the networking between the Sixtiers, and distribution of samizdat materials.

I. Pidkova allocates an essential role of M. Horyn in establishing the Ukrainian Republican Party (Pidkova, 2014). The author states the Horyn brothers together with L. Lukianenko initiated the creation of a new political unit unlike CPSU (the Communist Party of the Soviet 
Union), the only legal and monopoly on power at that time. Despite the declared need to terminate the CPSU's operation, the above persons admitted a possibility of the cooperation with well-judging, democratically-minded communists in order to achieve a strategic goal - to fulfill Ukraine's dream to be independent from Moscow. Moreover, it is identified an exceptional role of M. Horyn as a head of the political council of NRU in terms of networking and coordination of the efforts of political democratic parties.

\section{Conclusions}

Consequently, the analytical historiographical overview of activities of the Horyn brothers confirms they have become an object of the academic interest. The papers devoted to the history of the national liberation movement contain a piece of information on the dissident time of the Horyn brothers, their engagement in samizdat. Research studies on the issues of socio-political life in the independent Ukraine seek to fill this gap. They briefly define a role of M. and B. Horyn in the party building and participation in the work of the Verkhovna Rada of Ukraine of the first convocations.

A positive hallmark of the historical research is the progress in studying relevant personalities caused by the revival of public interest in the events taking place in the days of the Sixtiers and dissidents. However, only a small part of the research is devoted to the Horyn brothers and covers individual aspects of their activities. At the same time, there is a lack of complex research which would fully characterize the importance and significance of the activities of M. and B. Horyn for gaining Ukraine's independence, as well as their participation in the state building of Ukraine.

\section{References}

Batenko T. (1997) Opozytsiina osobystist: druha polovyna KhKh st. Politychnyi portret Bohdana Horynia [Opposition personality: the latter half of the XXth century. The political portrait of Bohdan Horyn]. Lviv: Kalvariia.

Batenko T. (1995) Svicha Mykhaila Horynia. Shtrykhy do portreta [A candle of Mykhailo Horyn. The touches to the portrait]. Kyiv: URP.

Bazhan O., Danyliuk Yu. (2000) Opozytsiia v Ukraini (druha polovyna 50-kh-80-ti rr.) [Opposition in Ukraine (the latter half of the '50s - '80s)]. Kyiv: Ridnyi krai.

Danyliuk Yu., Bazhan O. (2000) Ukrainskyi natsionalnyi rukh: osnovni tendentsii i etapy rozvytku (kinets 1950-kh - 1980-ti roky) [Ukrainian nationalist movement: primary trends and development stages (the late 1950s - 1980s)]. Kyiv: Ridnyi krai.

Boiko O. (2002) Ukraina u 1985 - 1991 rr. Osnovni tendentsii suspilno-politychnoho rozvytku [Ukraine in 1985 - 1991. Primary trends of the socio-political development]. Kyiv: IPiEND.

Hel I.A. (2013) Vyklyk systemi: ukrainskyi vyzvolnyi rukh druhoi polovyny KhKh stolittia [Challenges to the system: Ukrainian Liberation Movement of the latter XXth century]. Lviv: Chasopys.

Zaitsev Yu. (2007) Zhyttieve pereveslo Bohdana Horynia [Life journey of Bohdan Horyn]. Ukrainian Liberation Movement, vol. 11, pp. 233-249.

Zakharov B. (2003) Narys istorii dysydentskoho rukhu v Ukraini (1956-1987) [Essay on the histories of the dissident movement in Ukraine (1956-1987)]. Kharkiv: Folio.

Kasianov H. (1995) Nezghodni: ukrainska intelihentsiia u rusi oporu 1960-80-kh rokiv [Dissidents: Ukrainian intellectuals in the resistance movement of the 1960s - '80s]. Kyiv: Lybid. 
Kurnosov Yu. O. (1994) Inakomyslennia v Ukraini: (60-ti-persha polovyna 80-kh rr. KhKh st.) [Dissidence in Ukraine ("60s - the early 80s of the XXth century)]. Kyiv: In-t istorii Ukrainy. Miahka O. (2008) Natsionalno-vyzvolnyi rukh Ukrainy v 60-kh - poch. 90-kh rr. XX st. [National Liberation Movement in the ' 60 s - the early '90s of the XXth century]. Eminak, no. 1-4, pp. 84-89.

Mizhnarodnyi biohrafichnyi slovnyk dysydentiv krain Tsentralnoi ta Skhidnoi Yevropy y kolyshnoho SRSR (2006) [International Biographic Dictionary of Dissidents of Central and East European countries and the Former Soviet States]. Kharkiv: Prava liudyny. vol. 1, no 1, 516 p. no 2, $504 p$.

Naumova O. (2014) Publikatsii tvoriv samvydavu v ukrainskykh vydavnytstvakh za mezhamy SRSR (na materialakh fondu Naukovoi biblioteky Lvivskoho natsionalnoho universytetu im. Ivana Franka) [Publication of samizdat essays by Ukrainian publishers beyond the USSR boundaries (based on the repository materials of the Research Library of Ivan Franko National University of Lviv)]. Bulletin of Lviv University. Series bibliography, library science and information technologies, vol. 8, pp. 62-75.

Obertas O. (2010) Ukrainskyi samvydav: literaturna krytyka ta publitsystyka (1960-i-pochatok 1970-kh rokiv) [Ukrainian samizdat: literary criticism and publicism (1960s - the early 1970s)]. Kyiv: Smoloskyp.

Pidkova I.Z. (2014) Formuvannia bahatopartiinoi systemy v Ukrainskii RSR: uchast Narodnoi Rady u stanovlenni Ukrainskoi respublikanskoi partii ta Demokratychnoi partii Ukrainy [Formation of a multiparty system in the Ukrainian SSR: participation of the People's Council in establishing the Ukrainian Republican Party and the Democratic Party of Ukraine]. Bulletin of the National University «Lviv Polytechnic»: State and Army, vol. 809, pp. 84-88.

Rusnachenko A. M. (1998) Natsionalno-vyzvolnyi rukh v Ukraini: seredyna 1950-kh-pochatok 1990-kh rokiv [National liberation movement in Ukraine: the mid-1950s - the early 1990s]. Kyiv: Vyd-vo imeni Oleny Telihy.

Zinkevych O., Obertas O. (introduction) (2010) Rukh oporu v Ukraini: 1960-1990. Entsyklopedychnyi dovidnyk [The resistance movement in Ukraine: 1960 - 1990]. Kyiv: Smoloskyp.

Seko Ya. (2015) Lvivske seredovyshche shistdesiatnykiv [Lviv center of the Sixtiers]. Scientific notes of the Ternopil National Pedagogical University named after Vladimir Hnatyuk. Series: History, no. 1, vol. 1, pp. 88-93.

Ovsiienko V.V. (compiler) (2001) Ukrainska Hromadska Hrupa spryiannia vykonanniu Helsinkskykh uhod: [v 4 t.] [Ukrainian Helsinki Group: [in 4 vols.]]. Vol. 1: Personalities. Kharkiv: Folio.

Shanovska O. A. (2016) Velyka misiia Mykhaila Horynia [Big mission of Mykhailo Horyn]. Intelligentsia and power. Series: History, vol. 35. pp. 220-232.

Shelemei T.V. (2017) Socio-political activity of Mykhailo Horyn in 1961-1965 [Socio-political activity of Mykhailo Horyn in 1961-1965]. Scientific works of the historical faculty of Zaporizhia National University, vol. 48, pp. 181-187. 